\title{
Religious Ethos and Political Discourse, the Case of Senegalese Politicians
}

\author{
Dalla Malé Fofana
}

Université de Sherbrooke

\begin{abstract}
The population finds more and more difficulties to assess the scope and content of political declaration especially in terms of plausibility and the real intentions of the speakers. This is especially true for the Senegalese public who more and more loses confidence in the political class. The public tends to look at the identity of the political personality and its personal values (morality credibility) to determine what to make of his/her words. On their side, politicians also begin promoting their image through their speeches. At this level, religious ethics seems to be unanimously considered a criterion of good morality among Senegalese politicians. We will try to look through Perelman's theory of argumentation, which Amossy redefined, how, in order to reach the audience, politicians adapt their words to the public, and enhance principles cherished by the populations to win the battle of the image and confidence.
\end{abstract}

Keywords: political discourse, image, discursive ethos, pre-discursive ethos, Senegal, audience, influence

\section{Introduction}

The present study is a preliminary step toward a wider survey based on questionnaires and semi-structured interviews to be done with a particular audience. The subject of our study is a radio show made of interviews that a journalist makes with Senegalese politicians. I am focusing on the use of religion in the discourse of Senegalese politicians; the religious identity of the speaker is either clearly expressed or more implicitly referred to. From 2000 to 2007, Senegalese people are in a critical period learning about facts and fictions in political reality. After the euphoria of the fall of the party that had ruled the country for 40 years (the Socialist Party), the new president triumphantly elected in 2000 as the key to all problems, Abdoulaye Wade, proves not to be as convincing as expected. About a year before the end of his term and the following presidential elections, some among the private media aim at better informing the public for the presidential elections in 2007, ${ }^{1}$ to help them make the best choice possible. In this context, Keurgoumak, a Webradio based in Houston, Texas, United States, decides to inform migrants through interviews with politicians. The radio broadcast is called Pencum Senegal (discussion from/about Senegal). The target audience for the Webradio is the Senegalese diaspora, the Senegalese people who live abroad. The Senegalese emigrants have the right to vote and they play a key role in the economy of Senegal. This radio broadcast consists of interviews conducted by Pape Ale Niang, a renowned journalist, with prominent political figures from parties in the government, from opposition parties and civil

Dalla Malé Fofana, Contract faculty, Lettres et communication, Université de Sherbrooke, Sherbrooke, School of Education, Bishop’s University, Sherbrooke; main research field: French Studies, Linguistics, Discourse Analysis, Education, Linguistic Diversity, and French Second Language. 
society. The interviews take place in Senegal. But the program is broadcast via Internet from the United States. The particularity of Pencum Senegal is that the discussions are led in Wolof, the lingua franca of Senegal, to reach all segments of the Senegalese diaspora, especially that which speaks only French.

The election period that saw the birth of this radio show is marked by a deterioration of the image of the politician (Fofana 2015). Candidates for election, in power or in opposition, experience lack of confidence from the population. This situation pushes politicians to resort to strategies to reach the audience. It should be said that the gap keeps widening between the population and politicians. The situation is even more complex for the population that the politicians who issue statements may not want transparency. Therefore, the non-specialist audience abandons what is said and turns to the one who speaks. They prefer analyzing the personality of the speaker rather than the words spoken. As noted by Fortin (2005), not anyone can claim to know the policy, but one can claim to know the human being and to be able to tell the difference between a good or a bad man who will act in harmony with nature. For Fortin (2005), it is easier to understand to get a sense of who is talking than the words which are used, to get a better idea of the substance than the formulations, to grasp images better than good words (Fortin 2005, 9). ${ }^{2}$ It is much more convenient to have a better idea of him who is talking. This provides a more solid context for interpretation than to evaluate the words without knowing the speaker.

Therefore, the population is interested in the speaker's image, credibility, and values, in return, is aware of the listener's new approach, politicians, focuses on their image, and tries to promote one that strengthens and reassures. This adaptation of the speaker to the audience is based on showing that he is in line with the values and principles that audience considers important. If we take the case of Senegal, a country with great religious reputation, politicians aim at showing the image of a persona with impeccable religious ethics to win the trust of the population. But how is this religious ethics displayed?

\section{Theoretical Frameworks: Argumentation and Adaptation to the Audience}

The theoretical framework through which we approach the analysis of the discursive orientation of politicians is the theory of argumentation (Perelman and Amossy). The politicians have to promote an image of credibility to improve the impact on his words on the audience. This credibility goes according to Perelman, not by a claim from the speaker to the truth, but by the speaker conforming to the values he ${ }^{3}$ attributes to himself and most importantly to the audience. Those qualities which are endorsed by the speaker are in fact a reflection of the audience's actual or targeted values.

\subsection{The Discursive Ethos}

For Maingueneau and Charaudeau (2002), the image projected by the speaker, (ethos), is rhetorical. It is rooted in the performance of a speech and the way a speech is set, but not in the actual identity of the speaker. ${ }^{4}$ Amossy $(2000,4)$ points out that the image the speaker projects of himself in his speech has a huge impact of his credibility and authority. ${ }^{5}$ According to her, we should not underestimate the importance of ethos as the image that the speaker establishes of himself in his speech contributes powerfully to ensuring its credibility and authority. However Ducrot $(1984,201)$ quoted by Amossy $(2000,75)$ points out that in terms of image, it is not about flattering information that a speaker can give about himself in the content of his speech. Openly describing oneself may instead rebut the listener. But what serves the speaker is the impression given by the flow, warm, or severe intonation, word choice, arguments. Indeed Ducrot (quoted by Maingueneau and Charaudeau 2002) states that the ethos should not be the object of discourse. 


\section{The Corpus}

The show Pencum Senegal was broadcast from February 2006 to August 2006 via internet. The language used in the interviews is the Wolof, the vehicular language of Senegal. One of the particular features of the corpus is French and Wolof code switching. Interviews are initially posted on Keurgoumak radio Website. To build the corpus, to obtain a homogeneous set of interviews, we removed the interviews of personalities from the civil society and kept only those of the personalities in power and in the opposition. We have also removed the first interview, which was exploratory (for the radio show) in nature (live interview and call-in), and in length. The transcription system we adopt is the orthographic transcription without punctuation. To ensure the management of the corpus which size is quite significant (almost 700 pages), we have submitted it to a software Sato. It is a Text Analysis System Computer used on computer platforms like IBM PC and compatibles. This system is dedicated to the analysis of the content of the documents kept on a computer. It is designed by François Daoust. An important point to note is that the prosodic elements are represented in the corpus conventionally. But to adapt the corpus to the software Sato, we gave them a lexical form (see table attached).

\section{A Religious Image}

We believe that indeed the politicians can win the audience's confidence by presenting a positive image of themselves and of the audience. The creation of the image to be portrayed depends on the form a speech is set in as well as its meaning. In terms of form, it is of course the language (Wolof) and the style. As for the meaning, it includes for the speaker to show the audience that he shares its values and respects them. These values come from what Amossy $(2000,7)$ calls doxa. It is a set of beliefs, values, and opinions tied to those of the audience. This means that it must include the common opinions and irrefutable beliefs that are part of the cultural background of the audience. Religion is certainly one of those defining traits in Senegalese society.

\subsection{An Ethos of Establishment}

The religious aspect is certainly very established and linked to Senegalese culture. It is, as well as culture, a social background that is common. There is a syncretism, an adaptation of Islam to the Senegalese cultural specificities. Acknowledging and expressing that civilizational dimension, for a politician, is a sign of recognition (of local culture) and establishment. Religious values are expressed in various ways in different aspects of social life.

For example, in Senegal, there is a widespread socio-religious practice among Muslims and even Christians that is to check on each other at special occasions. It is, on the occasion of Muslim feasts, for people to ask about the health of each other and apologize for any offense each other, directly or indirectly, consciously or unconsciously has contracted. In the corpus, a politician took the opportunity of the interview, to pay his respects to the Senegalese population. He took the opportunity to apologize for all those whom he had offended during the course of the past year, and apologize to everyone who may have made offensive comments on him. He said a prayer for divine forgiveness (Ext. 1). This example, beyond its true sense, is a sign of an ethos of knowledge and respect from the speaker to the social and religious culture. This social practice of course originally applies more between neighbors, between individuals who live together in the same house, the same district, who in any case have the opportunity to meet. We note an adaptation of this practice to a larger and more complex reality: the media framework. Indeed, the original frame within which that type of apology applies is quite limited. It should be noted that with the development of the media (radio, television, 
newspapers), all public personalities are liable to offend listeners, viewers, readers, and citizens. The principle of this practice, which requires mutual apology whatever opposes you, has a social virtue of conflict resolution the same way the joking relationship does. Indeed, the joking relationship, based on a cultural agreement between specific ethnic groups, makes ego less predominant between people. It is a system that links ethnic groups (by pair) with a non-aggression pact. This system gives the mutual right to twinned ethnic groups to criticize each other and to accept criticism or mockery from each other. This practice is understood as a pacification tool, with its ability to resolve conflicts. The joking relationship is a particular combination of goodwill and antagonism, a friendly relationship within which is an apparent opposition that obeys conventional rules (Canute and Smith 2006, 6). ${ }^{6}$ In other words, it is a form of friendly relation, which is a unique combination of benevolence and antagonism, a friendship in which there is an apparent antagonism controlled by conventional rules. This is a phenomenon that is somewhat comparable to the "friendly rivalry," linking for example universities of Oxford and Cambridge (Mauss, Radcliffe-Brown cited by Canute and Smith 2006). Mauss (quoted by Canute and Smith 2006) emphasizes on the importance of these "joking relationships," which would be the opposite of avoidance (relatives to respect). But these phenomena must be studied together, to understand the logic that can fit together in society opposing forces of conjunction and disjunction.

Table 1

Ext. Socio-Cultural: Paying Homage to the Senegalese People

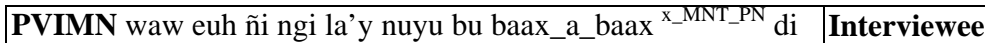
X_MNT_PN jott'al'i ziar ${ }^{\text {X_MNT_PN }}$ su'ñu m’bokk’u sénégalais yi nekk euh ${ }^{\mathrm{x} \_ \text {MNT }}$ ci_biti_m_reew raw'aat'i na ${ }^{\text {x_MNT }}$ tabaski ${ }^{\text {x_DXQ }}$ and sisters who are Senegalese/(.) abroad specifically/(.) in this bi nga xam ne wees'u na ñu ku'o ${ }^{\text {x_DSC_PN }}$ di leen baal'u aqq di Tabaski\(.) we apologize to them and ask for their forgiveness

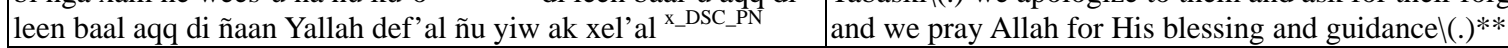

\subsubsection{Religion and Language: A More or Less Formally Expressed Faith}

Depending on the situation, the speaker can express more or less formally beliefs and religious values. In political discourse, evoking expressions of religious origin can confer an ethos of virtuous believing person to the politician who states them. We note that the multiple direct or indirect references to religion primarily have as objective to note that in all actions the speaker gets engaged to, he follows a particular religious ethics and morality.

On the lexical level, a significant term that can give an idea of the many references that speakers do to religion, is Yallah. It is the Wolof equivalent of the name of God, Allah in Islam. A political personality of Christian faith (John Paul Diaz) also used it to refer to God. Another term is used in the corpus. It is Borrom bi, the Owner. We find 419 occurrences of these three terms (Yallah, Allah, Borrom bi) across all speakers (Ext. 2). The speakers specifically recognize God's will upon every aspect of life, of their life. So instead of declaring that something did not work, the speaker will say that God has done (or decided) that that thing would not happen. Instead of saying, he won election; he will say God has made him be elected. Instead of saying that he overcame the obstacles on his way, he will say that God made him overcome them. Instead of saying he has the difficult task of speaking on behalf of the party, the speaker would say that God has subjected or put him or her to the task of speaking for the party (Ext. 2). A common phrase (16 occurrences) that is quite present in the corpus (Ext. 3) is in (if) shaa (wants) Allah (God). The equivalent of that term in the Wolof language is known as bu neex'e Yallah or bu soob'e Yallah (4 occurrences). It emphasizes that the speaker is counting on God's help to get things done (Ext. 5). 
Table 2

Occurrence of the Term: Allah

\begin{tabular}{|l|l|}
\hline Lexemes & Occurrence \\
\hline allah ('u/'i) & 64 \\
\hline yallah ('a) & 340 \\
\hline borrom ('m/bi) & 22 \\
\hline
\end{tabular}

Table 3

Awareness of God's Presence and Submission to Him

\begin{tabular}{|l|l|}
\hline Yallah def'oon ñu gagner & God made us win \\
\hline Yallah def mu réussir mission'm & God made him successful in his mission \\
\hline Yallah def nga nekk libéral & God has made a liberal of me \\
\hline Yallah jox ma ndam & God gave me victory \\
\hline Yallah yomb'al'al ku'o mu am diplôme & God made it easy for him to obtain his degree \\
\hline Yallah def'oon ba ma nekk avocat & God has made me get appointed as a lawer (is the trial) \\
\hline
\end{tabular}

Table 4

Different Forms of the Phrase In sha Allah

\begin{tabular}{|l|l|}
\hline In sha Allah' (u) (rabbi) & If God wants/God willing \\
\hline su neex'e Yallah & If God wants/God willing \\
\hline bu soob'e Yallah & If God wants/God willing \\
\hline
\end{tabular}

\section{Table 5}

Structure of the Phrase

\begin{tabular}{|l|l|l|l|}
\hline if & want & God & \\
\hline in & sha & Allah & Arabic \\
\hline su & neex'e & Yallah & Wolof \\
\hline bu & soob'e & Yallah & \\
\hline
\end{tabular}

A look at verbs associated with the expression of divine authority (Yallah) can give us an idea of the direction in which the word God is used. We have situations in which divine authority is presented as the source and the doer, with verbs such as $\operatorname{def}^{\mathrm{A}}$ (to do), $\operatorname{dog}^{\mathrm{B}}$ (to decide), $\operatorname{dimbal}^{\prime}{ }^{\mathrm{C}}$ (to help), $\operatorname{Man}^{\mathrm{D}}$ (to be capable of), $\mathrm{May}^{\mathrm{E}} / \mathrm{jox}^{\mathrm{F}}$ (to offer, to grant), $x a m^{\mathrm{G}}$ (to know). The action to doing (def) is displayed in different ways: def' $a l^{\mathrm{H}}$, def'oon ${ }^{\mathrm{I}}$, da fa def (Ext. 6). We find 35 occurrences of this verb in the corpus. The word $\operatorname{dogg}^{\mathrm{J}}$ literally indicates the action of cutting (12 occurrences). It is most often used in its noun form $n^{\prime}{ }^{\prime}{ }^{\prime} g^{\prime} a l^{\mathrm{K}}$. This is the idea of proceeding by decree, making a decision, in the sense of ordering, hence the phrase N'dog'al'u Yallah (Decree from God) and Yallah \{'a; mu o\} ku'o dogg'al (God is the one who ruled it this way). The verb to know ( $x^{\mathrm{L}}{ }^{\mathrm{L}}: 18$ occurrences) refers to the divine omniscience, while the verb can (man: 29 occurrences) carries the idea of omnipotence. The verb to help (dimbal'i) has 6 occurrences. The verb to offer (May, jox: 16 occurrences) is used in the sense of giving, assigning a favor. We also find other verbs like to create (sakk ${ }^{\mathrm{M}}$, bind $^{\mathrm{N}}$ : 25 occurrences), the verb to protect (sutura'l 0: 5 occurrences), the verb to test (natt ${ }^{\mathrm{P}}$, sas $^{\mathrm{Q}}: 8$ occurrences) and to ease (yomb'al ${ }^{\mathrm{R}}: 2$ occurrences). 
Table 6

Expressions of Divine Authority

\begin{tabular}{|c|c|c|}
\hline A & Yallah def'al ñu yiw ak xel'all(.) & May God grant us peace and guidancel(.) \\
\hline $\mathrm{B}$ & su ku'o dog'al'e ak jamm/ & If God makes it happen peacefully \\
\hline $\mathrm{C}$ & Yallah na leen dimbal'i/ba ñu am ci ndam & May God help us so that we have victory \\
\hline $\mathrm{D}$ & ni ma ku'o yaakaare'oon ne man'a dog'al mu dem'e nu'o nul(.) & God may make it happen the way I hoped\(.) \\
\hline $\mathrm{E}$ & kepp ku’o xam ne may na la nga agg nekk président & All those whom God granted the privilege of being president \\
\hline $\mathrm{F}$ & jox ma FEPP ndam/(.) & God has granted me victory in all these situations \\
\hline G & $\begin{array}{l}\text { rekk'a ku'o xaml(.) ma ngi seede lu'o Yallah mi nga xam ne/mi } \\
\text { ngi ma'y degg mi }\end{array}$ & Only God knows I take Him as a Witness \\
\hline $\mathrm{H}$ & di na ku’o ci def'al ay n'jar'iñ & God will make his activity fruitful \\
\hline I & def'oon ñu gagner ku'o ku'o ku ma ngi & God has made us win \\
\hline $\mathrm{J}$ & dog'al na nit ku TEEY x'eths la & God has made him a man with a cool temper $* *$ \\
\hline K & man'a dog'al mu dem'e nu'o nul(.) & God can decide for things to go this way \\
\hline $\mathrm{L}$ & mu'o'm... mii ma tiim xam na ne/(.) & He who sees all sees knows that about me/(.) \\
\hline $\mathrm{M}$ & yi bës bu Yallah sakk/(.) nga gis ci journaux yi & Every day that God creates/(.) we can see on newspapers... \\
\hline $\mathrm{N}$ & Yallah nu'o nu la ma bind'e/(.) japp na'a ne/nit & This is the way God has created me \\
\hline $\mathrm{O}$ & jigen Yallah da fa ku’o mës'a sutur'al ci fan & God is the guardian of women's dignity \\
\hline $\mathrm{P}$ & peut-être natt'u la bu fekk'e mbir mi & May be this the way God decided it... \\
\hline $\mathrm{Q}$ & position YI ñu nekk yëp/sas bu ñu tek lalparce que du lu neex de & $\begin{array}{l}\text { The position we have in the government is a task that God } \\
\text { has put us tolbecause it is not easy }\end{array}$ \\
\hline $\mathrm{R}$ & di ñaan Yallah mu yomb’al'al ñu lu’o le & We pray God to make things easy \\
\hline $\mathrm{S}$ & ma ngi cathédrale ma ngi jaam'u Yallah/(-) & I was in the church praying God \\
\hline $\mathrm{T}$ & mu'o’m...gëm'u'l Yallah|(-) & He... doesn’t believe in God \\
\hline $\mathrm{U}$ & Yallah'a xam na ñu bayyi rek/(.) & God knowns it all, let Him decide/(.) \\
\hline
\end{tabular}

But divine authority is not always presented as the active subject in the sentence. It may also be the object.

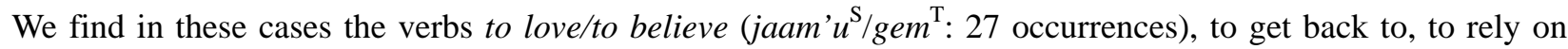
(bayyi ${ }^{\mathrm{U}}$ : 10 occurrences) to thank (sant: 12 occurrences). The verb to swear (Waat: 4 occurrences) and it's Arabic equivalents bi/wa (10 occurrences). It appears to be the strongest and most direct expressions of religious faith. That phrase means literally I swear to God. We find those phrases in various contexts. There may be cases where the speaker asks for witness to support the truth of his statements. For example, a phrase like Wax degg Yallah (37 occurrences) which means I speak the truth for the sake of Allah can be used as an adverb. The speaker who uses it indicates that he tells the truth, for God's sake, since God requires that the believer tells the truth. This idea is also found in other forms, in other phrases. We also have the phrase astafir' $u$ Allah which literally means, I ask forgiveness from Allah. It is a phrase used by a speaker who made a mistake, a lapse, or emitted offensive words. It is also interesting to note that the overlapping between Wolof, Arabic language and Islam is so strong that speakers from catholic faith may use the same phrase as the Muslim. This is the case of Jean Paul Diaz.

Table 7

Set Phrase

\begin{tabular}{|l|l|}
\hline astafiru Allah & I ask forgiveness from Allah \\
\hline Tabara faq'Allah & Everything from Allah is positive \\
\hline Yallah baax na & God is good \\
\hline sant Yallah & Thank God \\
\hline Seede Yallah & God is witness \\
\hline Ma sha Allah & (Since/as/the way) Allah wants it \\
\hline
\end{tabular}


The phrase Tabara fa q'allah is weaker than the others. This is a phrase which, inserted in a statement, can infer a sign of acceptance that any event is the will of Allah. The speaker may use it also to protect himself from the risk of contesting God's decision or denigrating a characteristic of God. The term literally means that blessing is upon anything God decides. It can give an idea of the state of mind of the speaker. The phrase Yallah baax na (Allah is good, kind) is quite similar to the previous one. It may be used to notify the confidence that the speaker has in God. We find some of these set phrases (Ext. 7) and others that can be inserted in the speech and adjusted to it (Ext. 8). In terms of the symbolic and argumentative dimension of these phrases, we find various cases emphasizing the presence of God's will in all physical and psychological events. They can also include the formulation of prayers (Ext. 9), praising God (Ext. 10, 11), or appear as acts of challenges based on religious faith (Ext. 12).

Table 8

Phrases More or Less Set

\begin{tabular}{|l|l|}
\hline dëgg'a neex (nak) Yallah & God urges us for the truth $^{7}$ \\
\hline Seede lu'o dëgg Yallah & If you take God as a withness \\
\hline sa'ma (sen/su nu) aqq'u Allah'i (taala) & My/their/our truth that God forces us to express \\
\hline $\begin{array}{l}\text { Wax dëgg (rek) te Yallah tax } \\
\text { wax (fa) dëgg Yallah }\end{array}$ & To tell the truth just for God's sake \\
\hline N'dog'al'u Yallah & God's decision \\
\hline Natt'u/sas'u Yallah & A test from God \\
\hline
\end{tabular}

Table 9

Prayer Formulation

\begin{tabular}{|l|l|}
\hline Yallah na ñu sutur'al ba nawet bii & May God grant us a good rainy season \\
\hline Yallah na leen li Yallah dimbal'i & May God help us \\
\hline Yallah na ku'o fi Yallah yem'al'e & May God stop this here \\
\hline Yallah na ñu ku'o Yallah: fay'al & May God reward him for us \\
\hline
\end{tabular}

Table 10

Faith Expression

\begin{tabular}{|l|l|}
\hline $\begin{array}{l}\text { man jurom benn'i mètre'u perkal } \\
\text { mu'o may topp bu ma de'e//(.) }\end{array}$ & $\begin{array}{l}\text { I will take with me only seven meters of Perkal (shroud) when I } \\
\text { die }\end{array}$ \\
\hline ngi cathédrale ma ngi jaam'u Yallah & In the cathedral I was praying God \\
\hline sas bu ñu Yallah tek la & This is a test that God submits us to \\
\hline mu'o bind'e nu'o nu/adina & It is God who created the world in this way \\
\hline nu'o nu la ma bind'e/(.) & It is God who created me this way \\
\hline Yallah mu'o'y tann kilifa & It is God who chooses leaders \\
\hline mu'o ku'o'y def ci nit & It is God who does this in an individual \\
\hline
\end{tabular}

Table 11

Act of Challenge, on the Basis of Religious Faith

\begin{tabular}{|l|l|l|}
\hline$a$ & ba illa yawm diini & .. Until the day of Judgment \\
\hline$b$ & man na ñu toog ci safara bu fekk'e ne & I can go to hell if... \\
\hline c & $\begin{array}{l}\text { ku jël'oon kaamin/ma xët ku'o } \\
\text { Bi Allah'i Wa Allah'i taalahi }\end{array}$ & $\begin{array}{l}\text { If you bring me a Koran I will swear my hand on it } \\
\text { I swear to God, the Most High }\end{array}$ \\
\hline$d$ & di nga ku'o lay'o ak sa borrom & Anyone will be held accountable in front of God \\
\hline$e$ & $\begin{array}{l}\text { bu dem'e élection législative } \\
\text { ala'kulli'alin/(.) di na perte }\end{array}$ & $\begin{array}{l}\text { If he goes to election ala kulli alin }{ }^{9} \text { (no matter what) he will } \\
\text { lose }\end{array}$ \\
\hline$f$ & aduna da fa'y tukki & This life will come to an end \\
\hline
\end{tabular}


Table 12

Exaltation of the Divine Dimension in Speech

\begin{tabular}{|l|l|}
\hline$h \quad$ Yallah nelaw'u'l gëm'u'l & God neither sleeps nor closes His eyes ${ }^{10}$ \\
\hline mu'o ku'o man/ & He is the one capable of that \\
\hline mu'o'm du juum & He doesn't make mistakes \\
\hline mi dara të'u'l & Nothing can repel His will \\
\hline mu'o man seytaane & He is stronger than Satan \\
\hline ku du'l da nga'y juuml & Nobody is perfect except God \\
\hline
\end{tabular}

\subsubsection{Between Language and Religion}

In addition to these, the interviewed political personalities use phrases that are indirectly linked to religion. The fact that a speaker comments on events using words with religious orientation or origin, may give the audience the impression that he stands above the fray. The choice of terms of Arabo-Islamic origin as Musiba or safaan (to designate a negative event) can provide this impression. Another example is the use of the Wolof phrase: doom'u Adama (son of Adam/man) instead of nit to designate a human being (Ext. 13). The fact that another speaker prefers the term lew (religious legality) to jaar yoon (constitutional legality) to describe an event can have a significant meaning for the audience. To define that kind of honesty we could say that religious honesty might refer to a behavior that is due to moral consciousness and not the fear of the law, which would be the driving force of honesty for no religious reasons. The politician who uses these kinds of terms may create the impression for the audience that he possesses them himself. In the particular Senegalese context, it may imply also that this ethos of honesty that the speaker promotes may free him from an image of corruptor that the political class tends to be labeled with. The absence of religious honesty could be defined by some to be the origin of the fraud that weakens the Senegalese political environment (Ext. 14).

We should point out that among the variety of phrases with religious connotations, some have gone through a more or less important grammaticalization process, hence, some are submitted to a loss of semantic content. This is explained by the fact that some phrases that have a strong original religious significance come to lose their original meaning. This transformation in terms of connotation may be accompanied by a phonetic transformation that can make the original form unrecognizable (Ext. 18).

A for syntax, it is possible to note as in the following structures that most of the time religious ideas are brought in using the same pattern as proverb (Fofana 2015). The sentence is based on two segments. The first segment has a governing role of a dogma, and the second one is a reflection about that first. This first segment is set in the form of a proverb; the second is a segment applied to the speaker (Ext. 15-17).

Table 13

Other Terms Significant Religious Connotation

\begin{tabular}{|l|l|l|l|}
\hline Doom'u Adama & Son of Adam & Nafsu/Baqqan & Human life \\
\hline musiba & Negative event & Ruuh & The soul \\
\hline Safaan & Wrong doing & yërëm'ande & Compassion \\
\hline seytaane & Satan & aafiya & Peace \\
\hline Aduna & Life on earth & fitna & Lack of peace \\
\hline Alaxira & Life in the hereafter & wër'sëg & Wealth granted by God \\
\hline Lew & Religiously legal & saafara'l & The fire of hell \\
\hline sell & Pure & kilifa & Respectable man \\
\hline seytaane & Satan & & \\
\hline
\end{tabular}


Table 14

From Constitutional Legality to the Religious Legality

PVIOS ... l'essentiel mu'o'y la nekk ci compte ya x_MNT ndax lew na wa la lew'u'l x_DSC lu'o lu la nit ñi war'a gëstu X_DSC_PN

PPIAA ... xaalis bi la lew mu’o’y bi nga'y ñacc...

I: ... the question to ask about what is in these bank accounts is/ is it legal or illegal (religiously legality) \this is what we must seek $\backslash($.

I: ... The money that is (religiously)legal is the one you earn form your sweat (as opposed to the money from corruption)

Table 15

Formal Aspect

\begin{tabular}{|l|l|}
\hline Dogme & $\begin{array}{l}\text { Liggéey'l aduna ngir sa alaxira'y ëlëk... } \\
\text { You have to work in this life for the hereafter... }\end{array}$ \\
\hline Application/Reinvestment & $\begin{array}{l}\text {. man nak bokk naa ci ñu'o ñu } \\
\text {... I'm one of those people }\end{array}$ \\
\hline
\end{tabular}

Table 16

Formal Aspect

\begin{tabular}{|l|l|}
\hline Dogme & $\begin{array}{l}\text { lu'o liggéey fii rek/(.) ëlëk di nga ku'o fa fekk/... } \\
\text { what you are doing here, you shall see the results in the } \\
\text { Hereafter... }\end{array}$ \\
\hline Application/Reinvestment & $\begin{array}{l}\text {. lu’o lu yëp ñakk gëm Yallah la } \\
\ldots \text { all these (bad actions) are only the result of a lack of belief in } \\
\text { God }\end{array}$ \\
\hline
\end{tabular}

Table 17

Formal Aspect

\begin{tabular}{|l|l|}
\hline Dogme & $\begin{array}{l}\text { nu nangu ku'o nak mu'y dog'al'u Yallahl(.) } \\
\text { we have to accept it as a decision from God }\end{array}$ \\
\hline Application/Reinvestment & $\begin{array}{l}\text { man da ma nangu dog'al lool/ } \\
\text { I am someone who accepts Allah's decision }\end{array}$ \\
\hline
\end{tabular}

The main part of these phrases may address or allude to the phenomenon of corruption, illicit enrichment. These kinds of declaration made by politicians are a way of cleaning themselves from the offending group. The main idea is that those who fall for corruption want to get more income than what God has supposedly decided that they would have (Ext. 19).

Table 18

More or Less Grammaticalized Religious Terms

\begin{tabular}{|l|l|}
\hline bës bu Yallah sakk & Every Day God makes \\
\hline PVIOS ... te bës bu Yallah sakk ñu’o ngi ci x_DSC_P1_PRG & $\mathrm{I}^{11}$... and every day that God make we are at work, on the job 1 \\
\hline jurom benn at'u Yallah & Seven years of God \\
\hline $\begin{array}{l}\text { PPIAW ... muñ'al na ñu Ablaye Wade jurom benn at'u Yallah } \\
\text { yu'o xam ne ni }\end{array}$ & $\begin{array}{l}\text { I: ... we have been patient with the president for six years of } \\
\text { God. }\end{array}$ \\
\hline n'dem ci Allah M. Seye & The gone-back-to-God (late) Mr Seye \\
\hline $\begin{array}{l}\text { PPIED ... and ak ay Dame Lo x_MNT n’dem ci Yallah ci } \\
\text { Aboubakri Sèye bi gaa ñu x_MNT... }\end{array}$ & $\begin{array}{l}\text { I: ... with Dame Lo/and The gone-back-to-God (late) } \\
\text { Aboubakry Seye who has left us/... }\end{array}$ \\
\hline la ilaha illa & Expression of surprise (but literally there is no God but Allah) \\
\hline $\begin{array}{l}\text { PPJAA la ilaha illa Allah x_2MNT x_ACCC wax nga dëgg } \\
\text { x_2MNT_PN }\end{array}$ & J: ilaha illa Allah// you're right \\
\hline musiba naar'u Allah la & Unfortunate like the fire of Allah (of hell) \\
\hline $\begin{array}{l}\text { PPJJB ... la mu jur France musiba naar'u ALLAH’I la } \\
\text { X_DSC_PN_PRG }\end{array}$ & J: ... this has caused nothing but a curse like that of hell \\
\hline ala'kulli'alin & Anyway (fatally as if decided by God) \\
\hline $\begin{array}{l}\text { PVIMS ... eh kaso nak ala_kulli_alin x_MNT ump'u'l ku’y } \\
\text { dund x_DSC... }\end{array}$ & I: ... and the prison Anyway/can happen to anyone \\
\hline
\end{tabular}


Table 19

Ethos of Honesty

\begin{tabular}{|l|l|}
\hline wër'sëg la ku'o'y suux'aat/ & The earthly properties need continuous care \\
\hline wër'sëg mu'o'y sonn ak liggéey & $\begin{array}{l}\text { The earthly properties are equivalent to the effort and work we } \\
\text { put to it }\end{array}$ \\
\hline sa wër'sëg mu'o toll nu'o nul & You cannot have more than what God has planned for you \\
\hline $\begin{array}{l}\text { nit nit/toog na kër'm Yallah wër'sëg'al'e ku'o lu'o xam ne ni/ } \\
\text { mais man'u ku'o liggéey xi gir'u dund'm }\end{array}$ & $\begin{array}{l}\text { A man sitting at home may acquire a wealth that he wouldn't } \\
\text { acquire in a lifetime }\end{array}$ \\
\hline
\end{tabular}

This presentation of religious ethos is displayed through the speech of the speaker. It is more or less formally expressed. We find statements by which the author qualifies himself with assets he attributes to himself. Those statements can also imply an image to the listener. In all cases, religion remains a central element in the speech.

\section{Conclusion}

We realize that religion holds an important place in the declarations of Senegalese political figures. The religious virtue that politicians claim is formally expressed. It can also be hidden. A careful choice of terms can therefore imply religious mindfulness to the audience. This position is understandable since politicians' ethos in Senegal tends to be more or less negative. To be convincing, according to Amossy, the speaker is more successful with the positive image he projects of himself than with the actual terms he uses. That positive image feeds on the audience deepest values and beliefs. In the case of Senegal, religion is one of those values. But we realize also that there is a strong overlapping between society and religion, local language and religion.

Formally expressing religious values, talking about them or attributing them to oneself could have various impacts. Just evoking them can also infer different things for the audience. Yet we have to point at another important question to conclude this observation. If an image can effectively be displayed through the way a discourse is conducted, the terms chosen (discursive ethos), we do have pre discursive ethos. It is an image that is constructed by the audience from the actions of the speaker independently from his declarations. Politicians may seem to place more effort in the construction of the discursive ethos while the pre discursive ethos (we might even say the postdiscursif ethos, i.e., a sort of after speech impression or effect) is decisive. Gilbert (2009, 7) notes that public distrust toward politicians who have been in power shows well in this American saying: "fool me once, shame on you; fool me twice, shame on me."

The last point is that the audience is not homogeneous, and may have different or opposite value or views. The audience may even want a total separation to be made between public life and faith which would be private. Can this difference be made? Is this separation possible? Even if not formally expressed, aren't the values (religious or not) of a person guiding his decisions? We will address these questions in a future paper, and more importantly the way the targeted audience feels about the kind of discourse we have analyzed in this study. The present study is a preliminary step to a series of questionnaires and semi-structured interviews which we will submit to the targeted audience to see what is important to him in a political discourse. In our study, all politicians state or suggest an image of virtue, especially religious. However, the population continuously witnesses a different demonstration on the field with cases of scandals and corruptions that are proliferating within politicians. The population also witnesses invectives and verbal attacks from among politicians. Politicians accusing each other of fraud may indicate that they do resort to fraud, which is religiously (since they claim it) immoral. If such is not the case, it means we have instances of false accusations made among politicians. But calumny too is immoral. 


\section{Prediscursif Ethos}

But does credibility depend only on the words one pronounces? Reputation can be based on actions, that is to say, the pre-discursive image. This form of ethos includes all expectations and representations that the speaker does not generate by his speech. The discursive genre, which is ideological positioning, also creates expectations on the side of the audiance. Amossy $(1999,14)$ notes that ethos can be built without the speaker knowing it; it is reputation. Isocrates quoted by Amossy $(1999,62)$ speaks of pre reputation. Apparently it is the "name" of the speaker that matters. It is not how the speaker is to be seen in his speech, but what is already known about him. Gilbert $(2009,6)$ brings in the concept of ethos to the credibility and reliability placed in an interaction partner. It would be, in international politics, for example, the approval rate, the "confidence value" or "credibility" that politicians have. Prediscursif ethos can sometimes be generalized and eventually include a public character class.

\section{Notes}

1. The corpus has been established from February 2005 to August 2006.

2. "Le corps plutôt que les mots, la substance plutôt que la forme, la 'bonne gueule’ plutôt que les 'belles paroles."

3. The pronoun he is used as a generic term, to indicate masculine as well as feminine.

4. "Il est attaché à l'exercice de la parole, au rôle qui correspond à son discours, et non à l'individu réel, appréhendé indépendamment de sa prestation oratoire."

5. "L’image que l'orateur projette de lui-même dans son discours... contribue puissamment à assurer sa crédibilité et son autorité (translate)."

6. "une combinaison singulière de bienveillance et d'antagonisme... une relation d'amitié dans laquelle existe un antagonisme apparent, contrôlé par des règles conventionnelles.”

7. "Therefore, I tell the truth to please God even if it may cause discomfort to some."

8. The fact of swearing on Allah or being ready to swear on the Koran is a strong guarantee of the truthiness of what one says. For the interlocutor to express verbally his disbelief even after this actual swearing (or readiness to swear on the Koran) is a serious threat to the face of both of the interlocutors.

9. The speaker states that segment in Arabic, and takes advantage of the metaphorical impact of code switching.

10. In other words God sees everything, which the speaker is conscious of, and thus considers.

11. I: Interviewee.

\section{Works Cited}

Amossy, Ruth. "Introduction la notion d'ethos de la rhétorique à l'analyse de discours (Introduction the Notion of Rhetorical Ethos in Discourse Analysis)." L'image de soi dans le discours: la construction de l'ethos (The Image of Self in the Speech: Ethos Building). Neuchâtel: Delachaux \& Niestlé, 1999. 9-22.

---. L'argumentation dans le discours (Argumentation in Speech). Nathan, Paris: Nathan, 2000. 247.

Canut, C. and Smith, E. "Pactes, alliances et plaisanteries (Pacts, Alliances and Jokes).” Cahiers d'études africaines 184 (2006). $<\mathrm{http}: / /$ etudesafricaines.revues.org/619804>.

Desmarchelier, Dominique. Après Perelman: quelles politiques pour les nouvelles rhétoriques (After Perelmann: Which Politics for Rhetorics)? Lyon: ENS Éditions, 2004. 145-7.

Dreyfus, Martine and Juillard Caroline. "Le jeu de l'alternance dans la vie quotidienne des jeunes scolarisés à Dakar et à Ziguinchor (Sénégal). Variation dans l'usage du français et du wolof (Alternance Game in Everyday Life for Young-Scholarized-in-Dakar-and-Ziguinchor (Senegal). Variation in the Use of French and Wolof)." Cahiers d'études africaines 163-164 (2001). <http://etudesafricaines.revues.org/115>.

Fortin, G. "L'Argumentation: genèse d'une anthropologie du convaincre (Argumentation: Genesis of an Anthropology to Convince).” 2005. <http: //halshs.archives-ouvertes.fr/docs/00/03/23/43/PDF/Argumentation.pdf>. 
Fofana, Dalla Malé. "La subjectivité journalistique en entrevue médiatique: une approche rhétorique et interactionnelle de l'émission Péncum Sénégal (Journalistic Subjectivity in Media Interview: A Rhetorical and Interactional Approach).” 2015. Moissonnage BAC: Collection moissonnée par Bibliothèques et Archives Canada; Lettres et sciences humaines-Thèses. URL: <http://hdl.handle.net/11143/7712>.

Gilbert, Michael A. "La normativité naturelle: une théorie de l'argumentation comme discipline engage (Natural Normativity: A Theory of Argumentation as an Engaged Discipline ).” Argumentation et Analyse du Discours 2 (2009): 2-13.

Keurgoumak, (2005). Amath Diouf, responsable, [En ligne]: last update unknown, <http://www.keurgoumak.com/>. Date of access 2006.

Maingueneau, Dominique and Charaudeau Patrick. Dictionnaire d'analyse du discours (Discourse Analysis Dictionary). Seuil, 2002, 661.

---. “Analyse du Discours: une entrevue avec Dominique Maingueneau (Discourse Analysis: An Interview with Dominique Maingueneau).” Revista Virtual de Estudos da Linguagem-ReVEL, Ano 46 (2006): 1-6.

Tutescu, Mariana. Le moment Ch. PERELMAN et L. OLBRECHTS-TYTECA (The Moment Ch. PERELMAN and L. OLBRECHTS-TYTECA). 2005. <http: //ebooks.unibuc.ro/lls/MarianaTutescu-Argumentation/4.htm>. Last update unknown (Date of access Mars 10 2011). 